\title{
Application of selected principles of the learner-centred approach to English grammar teaching
}

\author{
Gabriela Lojova
}

\section{DOI : 10.18355/XL.2017.10.04.23}

\begin{abstract}
This article provides a theoretical analysis of the possibilities of applying principles of the learner-centred approach to English grammar teaching. In the educational environment in Slovakia, the adoption of meaningful and active learning approaches as well as the creation of a positive classroom atmosphere are the most pressing needs. Some psychological and neuropsychological aspects underlying the importance of these principles are also discussed. Furthermore, in order to highlight their impact on the learning process, the author compares and contrasts traditional and learnercentred approaches.
\end{abstract}

Key words: English grammar teaching, learner-centred approach, meaningful learning, active learning, positive atmosphere

\section{Introduction}

Following the article which provided a survey of current research in the field of English grammar teaching in Slovakia and which highlighted crucial problems associated with the development of declarative and procedural grammar knowledge (Lojova, 2016a), this article focuses on further theoretical analysis in response to some questions that were raised. In so doing, it likewise refers to the article on the need to humanize English language (EL) teaching in Slovakia and to implement the learner-centred approach in our schools (Lojova, 2016b). The connection between these two areas is obvious. The most general recommendation for more effective EL grammar teaching is to apply the principles of learner-centred teaching in developing declarative as well as procedural grammar knowledge. Furthermore, our task is also to analyse other aspects that might help increase the effectiveness of English grammar teaching in Slovakia.

Nowadays, after more than forty years of its existence, the learner-centred approach, as well as various aspects of humanizing education in general, have been researched, theoretically analysed and discussed in numerous professional publications around the world. The approach as a widespread fundamental educational philosophy is complex and multifaceted. Various experts focus on different aspects depending on their professional interests, pedagogical experience or related topical problems in education in their environments.

For example, Nunan (1996) analyses the aspects related to the content and curriculum of English teaching. Tudor (1996) focuses on various learner variables, Weimer (2013) emphasizes the importance of developing independent learners, Freiberg (Rogers - Freiberg, 1994) provides readers with descriptions of experience and analyses of numerous examples of how Carl Rogers' principles work in American schools, and Campbell - Krysevszka (1992) provide teachers with a collection of classroom activities and methodological guidance.

The analysis of EL teaching in Slovak mainstream schools, characterized by a relatively long and firmly rooted history of traditional teaching, in the light of the 
basic learner-centred principles shows that some aspects could be considered more pressing. In my work as a pre-service and in-service EL teacher trainer, I have strived to instil the learner-centred way of pedagogical thinking in my students. Based on 20 years of discussing, reflecting on and analysing their learning and teaching experiences from primary and secondary education, I would point to the primary importance of principles such as meaningful and active learning and a positive classroom atmosphere.

\section{Meaningful and active learning}

In traditional education, teachers tend to be too content-centred. Consciously or subconsciously they attribute central importance to the curriculum, syllabus, prescribed content and textbook materials. They do not analyse them sufficiently from the perspective of their learners, i.e., their relevance and meaningfulness and how they prepare them for real life communication in EL. The consequences are multifaceted: 1. Learners are demotivated as they do not see the point in learning the content. Therefore they do not participate actively in learning tasks, they might tend to avoid classes or act out in various ways. 2. Learners easily forget what they have learnt due to weak associations - memory connections. 3. They create communication barriers which may undermine their self-confidence. 4 . They may develop negative attitudes towards EL learning and school in general.

In addition to ample empirical evidence, many research studies and extensive scientific knowledge point out the mechanisms underlying the effectiveness of meaningful learning. It is provided by neurosciences explaining neural mechanisms such as the neurophysiological and neuropsychological basis of memory functioning. Neurobiology and cognitive psychology provide the evidence that the brain is designed to learn constantly, to network and to seek meaning (Schumann et.al, 2004, Blakemore - Frith, 2005, Kellogg, 2012, Paradis, 1994, 2009, etc.). The networking of neurons through synaptic connections in the brain and the creating of meaningful associations form the very fundamental base of effective learning. Sensory data is converted into meaning, as it is categorized as information, then codified and constructed into meaning. Respecting these natural mechanisms in education results in so called Brain compatible or Brain-based teaching (Jensen, 1996, 2007, Caine Caine, 1994). It means that everything in education is organized around the basic principles of how our brain learns best.

Even if the specialized research in brain functioning and foreign language learning and teaching is still in its infancy, the general knowledge of the neurobiology of learning can be easily applied. The best learning occurs when the brain must activate more connections - the greater the number of associations that the brain elicits, the more firmly the new information is "woven" into a learner's body of knowledge neurologically. What does it mean practically in EL teaching? How can more connections be activated? Through meaningful learning. The best meaning is created through the learner's own life. As Brooks and Brooks say, "There is no meaning in textbooks. There is no meaning from the presenter. There is only meaning from within learners." (in Jensen, 1996:196). Learners create meaning for themselves in what they learn. In EL learning they connect new words, phrases and structures with their own inner images, their inner picture of reality. This picture is determined not only by sensory input; it is also modified by the learner's real life experiences, knowledge, emotions, opinions, interests, needs, and developmental and individual differences. 
Therefore, whatever we teach must be adapted to what goes on in our learners' minds and associated with their lives. Each topic, any learning content should be personalized so that learners can connect such new information with their existing body of knowledge, create multiple associations and construct a more complex network. Personalization is the key phenomenon in meaningful EL teaching (Griffiths - Keohane, 2001, Lojova et al, 2011). Therefore, it is obvious that in order to achieve meaningful learning the content and teaching materials are of fundamental importance. To personalize learning as much as possible, textbook materials must be constantly modified. In addition, learners may use their own materials that they are interested in to read, listen to or watch or to discuss problems, opinions or questions they bear in their minds, etc. Teachers tend to feel too responsible for the resources. As D. Garvie stated, "Teachers are notoriously bad at recognizing one of the best teaching resources of all - the human beings in the classroom." (unknown resource).

In traditional EL education, learners are accustomed to relatively passive learning and the teacher is considered the main source of information. However, nowadays learners are exposed to varied resources and an enormous amount of information in their everyday life. Based on the principles of social constructivism, they need to acquire information on their own and analyse, sort and make it meaningful in their own unique way. As a result, the role of teachers has changed considerably. The teacher is a facilitator who organizes the environment and conditions so that learners can take on their own meaning in learning content and create multiple associations to learn more effectively. He/she is supposed to provide tasks that stimulate active learning such as problem solving, discussions, experimenting and projects, and learning tasks that challenge learners' full mental capacity, stimulate curiosity and intrigue, while prompting learners to discover meaning for themselves. Relevant language learning activities must include or simulate the tasks learners will have to face in their real life EL communication. If a teacher facilitates language learning in this way, learners are fully involved in activating various components of their cognitive and affective endowment. In so doing, they can realize their full potential and their need for selfactualisation can be fulfilled, which, according to Maslow's theory of hierarchy of needs, is the strongest motivation. In addition, teachers are supposed to guide learners in developing their metacognitive skills and awareness, help them become aware of their learning styles and develop effective learning strategies not only for their classroom learning but also for their out-of-school and life-long EL learning.

These general principles and strategies should be applied also throughout all of the stages of K. Johnson's model of the teaching of English grammar, which is based on a Piagetian understanding of learning a foreign language as developing cognitive skills (Johnson, 1996, Lojova, 2011b, Lojova, Kostelníkova, 2014). When learning declarative knowledge, learners are supposed to create the proper inner representation of the EL grammar system, i.e., functional-structural characteristics as a database for language production. It takes the form of a set of semantic networks as well as a general set of interpretative procedures for using the knowledge. At the declarative stage, the information is usually provided through instruction. The teacher may employ diverse strategies, methods and techniques to assist learners to construct their own comprehensible inner representations of target language structures, i.e., to comprehend grammar rules in their own way, which is the starting point for proceduralization. He / she should provide language learners with a wide variety of stimuli (verbal, nonverbal, visual, auditory, kinaesthetic etc.) so that each learner can consciously or subconsciously select the ones that best match his or her learning styles, cognitive needs and individual characteristics. In creating procedural grammar knowledge, automation is a fundamental component of skill development, because a 
newly learned skill takes up a great deal of channel capacity. The role of automation is to free important conscious attention for the higher-level tasks which comprise real life EL communication. When trying to use grammar rules correctly, learners tend to have problems in creating a general set of interpretative procedures for the application of the data in different contexts. It means that learners may understand how to create a given grammar structure, yet they are unsure about how the structure functions in various contexts. It is even more confusing when they are supposed to choose from two or more structures which are grammatically correct and possible in a given context but they may change the meaning to some extent. As our research findings show, this is one of the most pressing (and chronic ?) problems of secondary school EL learners in Slovakia (Lojova, 2011b, Lojova et al, 2015). To properly comprehend the varied functions of a given structure, tuning, as an inseparable part of proceduralization, is of essential importance. The initial, subjectively distorted comprehension of declarative knowledge is gradually corrected, i.e., tuned. Practically, it means that learners first understand grammar rules in their own unique way and then gradually clarify and check their hypotheses about the functional characteristics of a given structure. They generalize, fill in missing or misunderstood information, reinforce correct rules and eliminate incorrect ones. It is obvious that tuning is a long-term process based on foreign language perception and production in guided practice and real life situations. The result of sufficient tuning is that learners fully understand not only the form but, crucially, the possible meanings and functions of a given structure in various contexts. This is demonstrated particularly by the ability to use similar or ambiguous structures correctly and appropriately in a given communicative situation.

These brief characteristics clearly demonstrate that meaningful context and active learning are of fundamental importance for effective tuning. Only through experiencing how grammar structures function in their real life situations can learners create multiple associations with their previous knowledge and experience, which enables them to fully comprehend the functional-structural characteristics necessary for EL communicative skills and competences. Therefore, they need to practice grammar in diverse personalized contexts featuring communicative and productive learning tasks in (simulating) real life situations inside and outside the classroom. Furthermore, in accordance with K. Johnson's model of grammar teaching, in instructed settings teachers should carefully consider the amount of teaching learning time devoted to the stages of the learning model. Generally speaking, it is recommended to reduce a traditionally overemphasized explicit focus on declarative knowledge, as well as the amount of time and learner's potential spent on focused tasks and decontextualized exercises. Instead, much more time and energy should be devoted to communicative and productive tasks and meaningful activities. In addition, an essential prerequisite for successful proceduralization and tuning is the proper understanding of declarative knowledge. However, when learning declarative grammar knowledge, the set of interpretative procedures for using a structure in varied contexts cannot be fully understood at that time, as it is usually falsely believed. Therefore learners cannot be expected to immediately comprehend the rules and use them correctly. Practically, it means that they may understand how to create a given grammar structure yet are unsure how the structure functions in dynamically changing contexts, i.e., when and how to use the structure appropriately to communicate an intended meaning. It is mainly due to varied functions of English grammar structures in different contexts, as they are considerably subjectively or contextually determined. Therefore, however excellently a teacher may explain the functions of a learnt grammar structure, it is impossible to clearly comprehend all of 
its possible functions. The only way to get it is to experience its real functioning in communicative situations and in various meaningful contexts. So it is obvious that the processes of learning declarative and procedural knowledge co-occur to some extent and determine one another. When declarative knowledge is insufficient, there cannot be adequate procedural knowledge and vice-versa. In addition, there are other reasons why Slovak learners of English as a foreign language might have problems with the proper understanding of grammar rules. Some linguistic, pedagogical and psychological aspects underlying these problems have been theoretically analysed (Lojova et al, 2015). The formulated hypotheses are due to be tested by a research team at the Faculty of Education of Comenius University with the support of VEGA Project \# 1/0495/17 of the Slovak Ministry of Education entitled The interrelation between mental representations of the English language system, performance in metalinguistic tasks and production in communicative situations in English language teaching.

\section{Positive atmosphere}

A positive classroom atmosphere is another essential feature of the learner-centred teaching which deserves much more emphasis in EL grammar teaching as well as teaching in general in Slovak mainstream schools. Empirical evidence as well as neuroscience have provided research findings that support the hypothesis that positive emotions and underlying neurophysiological processes are fundamental for optimal neural networking. In addition, they increase the learners' potential, motivation, risktaking, persistence and self-confidence and lead to active participation and selfactualization. Furthermore, extensive empirical and research evidence demonstrates that classroom anxiety has a negative impact on creating and retrieving memory association (Machacova, 1997, Arnold, 2002, Gkonou et al, 2017). The overall atmosphere has a significant impact on everything that goes on in a classroom, including the learner's perception, thoughts, feelings, motivation, attitudes, behaviour and performance. In spite of these facts, in traditional educational settings, learners experience considerable stress, frustration, conflict and various negative emotions inhibiting effective learning. Many teachers still tend to build their authority on their dominant role, power and strict approach while insisting that learners work on assigned tasks even if they find them inappropriate, useless or boring.

The social climate in a classroom and the related emotional dynamism is a very complex phenomenon determined by various psychological aspects and psycho-social relations. The different classroom relations (i.e., teacher - learner (s), learner(s) teacher, complex peer-relations) represent a multifaceted and complex issue. These relations have been analysed by social and educational psychologists providing teachers with detailed professional guidance for their facilitation. Generally speaking, relations should be open and fair, and based on mutual trust and respect. Even if all of the participants contribute to a classroom atmosphere, the teacher's role is of paramount importance. Along with the proper facilitation of meaningful learning, and the use of humour, games, and interesting activating tasks, the teachers' positive mind-set and approach to learners is essential. They have to understand the importance of establishing a close rapport with their learners. Emotions are infectious. If a teacher radiates positive emotions, they spread in all directions and naturally transmit to learners. Learners can easily be inspired by a teacher's positive energy, enthusiasm and love for EL. Most of all they have to feel the teacher's love for them, which makes them feel secure, trusted and supported. As Rita Pierson said in her presentation, "Learners learn most from teachers whom they love and they love teachers who love them."

(https://www.ted.com/talks/rita_pierson_every_kid_needs_a_champion). 
The underlying source of this positive mind-set is the teacher's general approach to learners and the dominant focus on their strong points and positive features. This seems to be one of the fundamental differences between traditional and learnercentred teachers. Realizing this fact may be a starting point in the process of changing the pedagogical thinking of traditional teachers. Thus, the key recommendation is:

\section{Perceive your learners positively!}

Each human being, each learner has strong and weak points, positive and negative characteristics. In traditional education, teachers tend to be negatively biased. They focus on learners' mistakes, weaknesses and misbehaviour. In so doing, they falsely believe that it is for the learners' benefit, as they help them learn, improve and behave properly and thus become "better people". They repeatedly correct learners, give them bad marks, reprimand, scold and reproach them. Learners can tell numerous stories of experiencing humiliation, intimidation or hurtful ironic comments. On the other hand, what is done correctly and properly is often ignored or considered natural and not deserving special attention. Obviously, such negative approach could have a significant impact on learners' self-esteem, motivation and attitudes to teachers and learning. It undermines their self-confidence and might even lead to the development of an inferiority complex, which considerably hinders their communication in EL. A logical consequence is that they do not develop their capabilities sufficiently and their achievements do not reflect their natural potential. Apart from this impact on learners' cognitive and affective development, in such classrooms there must be numerous behavioural and discipline problems. When dealing with learners' misbehaviour, traditional teachers tend to apply various forms of punishment generating negative emotions, and in so doing multiplying a negative learning atmosphere. The source of this negative bias is obvious: the traditional education that the teachers themselves were exposed to in their primary and secondary education and usually also in their families. They consciously or subconsciously copy their teachers as role models, which is a natural psychological phenomenon. They may not critically analyse and reevaluate their approach in the light of currently dominant humanistic educational theories, which is also the result of traditional teaching focused on accumulating encyclopaedical knowledge instead of developing critical thinking, skills and competences.

The learner-centred teaching is characterised by a fundamentally different approach: Guided by the interiorized principles of Carl Rogers's philosophy, teachers approach learners as unique, valuable and capable human beings (Rogers - Freiberg 1994). They accept learners as they are, searching for their strong points and positive features. In so doing, they facilitate their learning in such a way that learners can develop their EL skills and communicative competence through these strengths within their potential. As each human being is different, learners are not expected to be equally good at everything. Therefore their results are not compared in a competitive way. Higher achievements in one area and lower in another are considered very natural. This approach is fully in accordance with Howard Gardner's theory of multiple intelligences, one of the fundamental sources of educational philosophy in many highly developed countries (Gardner 1999, Lojova 2011a). When encouraged, supported and positively evaluated for their achievements, learners feel recognized, trusted and valued, which considerably increases their motivation. They develop selfesteem and overcome barriers, which prompts them to better communicate in EL spontaneously. In addition, in learner-centred teaching, mistakes are approached as a natural part of learning and not as a failure to be punished. The complex topic of 
mistake treatment and the humanistic approach to assessment and evaluation in general and specifically in teaching a foreign language is analysed in numerous methodological and psychological publications (e.g., Kosova, 1997, Fontana, 1997, Gondova, 2010, Karikova, Oravcova, 2011). Furthermore, when dealing with discipline problems, instead of punishing misbehaviour, teachers encourage and reward required behaviour. Due to the natural human need for success and positive reinforcement, rewarded behaviour is repeated and negative behaviour or discipline problems are gradually reduced or even eliminated. If there are more serious problems, the teacher's task is to search for the reasons behind them and in cooperation with concerned (involved) student, to look for solutions. As a matter of fact, any violation of discipline is a reaction to inappropriate stimuli from the environment and a signal that some of the learners' needs are being frustrated. Definitely it is not the natural need of learners to misbehave that must be suppressed, as traditional teachers often tend to believe. The psychological basis underlying the effectiveness of such positive approach is obvious: the natural human need to experience positive emotions as well as the need to be successful, valued and to achieve full self-actualization.

\section{Conclusion}

As it is obvious from the theoretical analysis, applying the principles of meaningful learning, active learning and positive atmosphere can undoubtedly increase the effectiveness of EL grammar teaching and developing learners' communicative competence. In summary, the basic recommendations or "golden rules" for teachers are as follows:

Focus on your learners and do your best to know them. Bring their everyday life to the EL classroom. Accept them as they are, don't try to change them! Don't expect all learners to be equally good at everything! Each learner has strong points - find them, develop and build EL learning on them!

As Sarah Mercer says in her presentation (https://iatefl.britishcouncil.org/2017/session/plenary-session-sarah-mercer), "Trust your learners!- you will be surprised, how much they can do on their own, how they can communicate, what questions they are able to ask, what they can teach you, how meaningful they can make your classes, how independent they can become, how much they will open their hearts and minds."

The article was written with the support of VEGA Project \# 1/0495/17 of the Slovak Ministry of Education entitled "The interrelation between mental representations of the English language system, performance in metalinguistic tasks and production in communicative situations in English language teaching" carried out at the Faculty of Education of Comenius University in Bratislava.

\section{Bibliographic references}

ARNOLD, J. 2002. Affect in language learning. Cambridge: Cambridge University Press. ISBN 978-0521659635.

BLAKEMORE, S. J. - FRITH, U. 2005. The learning brain: lessons for education. Australia: Blackwell Publishing. ISBN 978-1-4051-2401-0.

CAINE, G. - CAINE, R.N. (eds.). 1994. Making connections: Teaching and the Human Brain. Menlo Park, California: Addison-Wesley. ISBN 978-0201-490-886

CAMPBELL, C. - KRYSEVSZKA, H. 1992. Learner-based Teaching. Oxford: Oxford University Press. ISBN-13: 978-0194371636.

FONTANA, D. 1997. Psychologie ve skolni praxi. Praha: Portal. ISBN 80-71780663-4. 
GARDNER, H. 1999. Intelligence reframed. Multiple intelligences for the $21^{\text {st }}$ century. New York: Basic Books. ISBN 978-04650-26-111.

GKONOU, CH. - DAUBNEY, M. - DEWAELE, J-M. (eds.) 2017. New insights into language anxiety. USA: Multilingual Matters. ISBN 9781783097715.

GONDOVA, D. 2010. Taking first steps in teaching English: Assessing learners. Žilina: EDIS vydavatelstvo Zilinskej university. ISBN 978-80-554-0236-9.

GRIFFITHS, G - KEOHANE, K. 2001.Personalizing language learning. Cambridge: Cambridge University Press. ISBN 978-0521-633-642.

JENSEN, E. 1996 (2008). Brain-based learning. CA: Turning Points Publishing. ISBN 0-9637832-1-1.

JENSEN, E. 2007. Introduction to Brain-compatible learning. CA Thousand Oaks:

Corwin press. A SAGE publications company. ISBN-13: 978-1412954181.

JOHNSON, K. 1996. Language Teaching and Skill Learning. Oxford: Blackwell Publishers. ISBN 0-631-16877-X.

KELLOGG, R. T. 2012. Fundamentals of cognitive psychology. California: SAGE Publications, Inc. ISBN 978-1-4129-7785-2.

KOSOVA, B. 1997. Hodnotenie ako prostriedok humanizacie skoly. Banska Bystrica: Univerzita Mateja Bela. ISBN 80-8055-067-0.

LOJOVA, G. 2011a. Individualne osobitosti pri uceni sa cudzich jazykov I. Bratislava: Vydavatelstvo UK. ISBN 80-223-2069-2.

LOJOVA, G. 2011b. Teoria a prax vyucovania gramatiky cudzich jazykov. Bratislava: Z-F LINGUA. ISBN 978-80-89328-53-6.

LOJOVA, G. 2016a. Sucasny stav skumania vyucovania gramatiky anglickeho jazyka na Slovensku. In: XLinguae, vol. 9, n. 3, pp. 70-80. ISSN 1337-8384.

LOJOVA, G. 2016b. Humanizing English language teaching in Slovakia. Xlinguea, vol.9, n. 4. pp. 30-36. ISSN 1337-8384.

LOJOVA, G. - FARKASOVA, E., - PCOLINSKA, A. 2011. Vyuzivanie personalizacie vo vyucovani anglickeho jazyka $\mathrm{v}$ primarnom vzdelavani. Bratislava Z-F LINGUA. ISBN 978-80-89328-62-8.

LOJOVA G. - KOSTELNIKOVA, M. 2014. Enhancing the Effectiveness of Teaching EFL Grammar in Slovakia. In: Studies in Foreign Language Education vol. 6, pp. 24-40. Kolin: Kirsch Verlag. ISBN 978-3-943906-12-.7

LOJOVA, G. et al. 2015. Deklarativne a proceduralne vedomosti vo vyucbe anglickeho jazyka. Bratislava: Univerzita Komenskeho. ISBN 978-80-223-3754-0.

MACHACOVA, H. 1997, Stres, rekuperace a kontrola stresu. Ceskoslovenska psychologie, vol. 41, n.2, pp. 139-146. ISSN 0009-062X.

NUNAN, D. 1996. The learner-centred curriculum. Cambridge: Cambridge University Press. ISBN 0-521 358434.

KARIKOVA, S. - ORAVCOVA, J. 2011. Psychologia v edukacii. Banska Bystrica: Obcianske zdruzenie Pedagog. ISBN 978-80-557-0123-3.

PARADIS, M. 1994. Neurolinguistic aspects of implicit and explicit memory: Implications for bilingualism and SLA. In N.C. Ellis (ed.), Implicit and explicit learning o languages (pp.393-420). London: Academia Press. ISBN 978-0122-374753.

PARADIS, M. 2009. Declarative and procedural determinants of second languages. Amsterdam: John Benjamins Publishing Company, ISBN 978-90-272-4176-4.

ROGERS, C. - FREIBERG, H.J. 1994. Freedom to learn. NY: Macmillan. ISBN 002-403121-6.

SCHUMANN, J. H. et al. 2004. The Neurobiology of Learning. Perspectives from Second Language Acquisition. London: LEA. ISBN 0-8058-6141-6.

TUDOR, I. 1996, 2009. Learner-centredness as language education. Cambridge: Cambridge University Press. ISBN 052148097. 
WEIMAR. M. 2013. Learner-centered teaching: Five key changes to practice. CA: John Wiley \& Sons, Inc. ISBN 978-1-118-11928-0.

Words: 4307

Characters: 30156 (16,75 standard pages)

Gabriela Lojová

Department of the English language and literature, Faculty of Education, Comenius University

Račianska 59

Bratislava 81334

Slovakia

lojova@fedu.uniba.sk 